\title{
PENGARUH PERBEDAAN PERSENTASE PENAMBAHAN GLISERIN DAN KONSENTRASI LARUTAN EKSTRAK GAMBIR TERHADAP BEBERAPA SIFAT FISIKA DAN KADAR TANIN TINTA STEMPEL
}

\section{Influence of Difference Percentage of Glycerin and Concentration of Solutions of The Gambir Extract on Physical Properties and Content of Tannins Stamp Ink}

\author{
Silfia*, Hendri Muchtar, dan Failisnur \\ Balai Riset dan Standardisasi Industri Padang \\ JI. Raya LIK No. 23, Ulu Gadut, Padang \\ *e-mail: silfiabintiarsul@yahoo.com
}

Diterima: 9 Februari 2015, revisi akhir: 20 Mei 2015 dan disetujui untuk diterbitkan: 25 Mei 2015

\begin{abstract}
ABSTRAK
Gambir berasal dari ekstrak daun tanaman Uncaria Gambier Roxb, mengandung senyawa katechin dan tanin yang termasuk golongan senyawa polifenol. Ekstrak gambir jika ditambahkan dengan garam ferosulfat akan membentuk senyawa komplek yang dapat memberikan warna hijau sampai hitam dan dapat digunakan sebagai pewarna pada tinta stempel. Penelitian ini bertujuan untuk melihat sejauhmana pengaruh penambahan gliserin dan konsentrasi larutan ekstrak gambir terhadap beberapa sifat fisika dan kadar tanin tinta stempel. Pembuatan tinta dilakukan melalui proses pencucian gambir, penyaringan, pembuatan cube black, pelarutan dan formulasi. Pembuatan tinta stempel dilakukan dengan rancangan acak lengkap non faktorial dengan variasi konsentrasi gliserin $(0 \%, 15 \%, 20 \%, 25 \%$, dan $30 \%$ ) dan konsentrasi ekstrak gambir (25\%, 30\%, 35\%, 40\%, dan 45\%). Hasil penelitan menunjukkan bahwa penambahan gliserin dapat meningkatkan beberapa sifat fisika terutama terhadap homogenitas tinta. Perlakuan terbaik diperoleh pada penggunaan ekstrak gambir $35 \%$ dengan $\mathrm{pH} 3,27$, padatan total $41,33 \%$, kadar tanin $2,58 \%$, pengamatan visual terhadap kekuatan pewarnan jelas dan rata, kekentalan sedang, tidak mengembang dan tidak lengket serta homogen.
\end{abstract}

\section{Kata Kunci: Ekstrak gambir, konsentrasi gambir, gliserin, tinta stempel}

\begin{abstract}
Gambier extract derived from leaves of Uncaria Gambier Roxb contain catechin and tannin which belonged to polyphenolic compounds. Gambier extract when added with ferosulfat salt will form a complex compound that can give a green color to black and can be used as a dye in the stamp ink. This study aims was to see how far the effect of adding glycerin and concentration of the Gambier extract solution against some physical properties and levels of tannin stamp ink. The ink manufacturing was done through a washing process of gambier, filtering, cube black manufacture, dissolution and formulation. The making of the stamp ink was done by a non factorial completely randomized design with a variation of the concentration of glycerin $10 \%$, $15 \%, 20 \%, 25 \%$, dan $30 \%)$ and the concentration of the extract gambier $(25 \%, 30 \%, 35 \%, 40 \%$, dan $45 \%)$. Results of the research showed that the addition of glycerin could increase some physical properties, especially against the homogenity of the ink. The best treatment was obtained on the use of gambier extracts $35 \%$ with $\mathrm{pH} 3.27$, total solids $41.33 \%$, tannin content $2.58 \%$, visual observation of color strength was clear and flat, viscosity was medium, not expand and not sticky, and homogeneous.
\end{abstract}

Keywords: Gambier extract, gambier concentration, glycerin, stamp ink 


\section{PENDAHULUAN}

Gambir merupakan salah satu komoditi unggulan Propinsi Sumatera Barat, bahkan juga termasuk produk unggulan Indonesia dengan produksi tahun 2013 adalah 14.220 ton dan luas lahan $23.537 \mathrm{Ha}$. Gambir diekspor ke India, Pakistan, Bangladesh, Singapore dan negara lainnya dalam bentuk gambir mentah (Badan Pusat Statistik, 2014).

Komposisi utama gambir adalah senyawa tanin sebagai asam katechu tannat $(20-55 \%)$ dan katekin $(7-33 \%)$. Kedua senyawa ini merupakan senyawa yang digolongkan ke dalam golongan fenol alam dengan struktur flavonoid, sedangkan senyawa lain dalam jumlah kecil yaitu pyrocatecol (20-30\%) seperti quersetin (2-4\%), katechu merah (3-5\%), gambir berfluoresensi (1-3\%) fixed oil (1-2\%) dan sedikit lilin (1-2\%) (Muchtar, 2007, 2012; Nazir, 2000; Noveri et al., 2012).

Zat warna alam tumbuh-tumbuhan pada dasarnya adalah tanin. Ada dua jenis golongan tanin yang dapat dihidrolisa dan tanin yang tidak dapat dihidrolisa atau tanin kondensasi. Tanin yang terdapat dalam gambir adalah jenis tanin yang tidak dapat dihidrolisa dengan asam ataupun basa. Senyawa tanin memberikan rasa sepat dan menimbulkan warna kuning, kecoklatan dan bahkan sampai hitam sehingga dapat digunakan sebagai pewarna alam pada industri tekstil (Failisnur dan Sofyan, 2014). Tanin gambir juga dapat digunakan sebagai penyamak kulit (Ardinal et al., 2013). Zat warna yang terbentuk dari hasil pembentukan senyawa komplek dapat digunakan sebagai bahan baku dalam pembuatan tinta (Yerimadesi, 2001; Muchtar, 2012; Lucida, 2007).

Semakin tinggi kandungan tanin maka semakin tua warna yang dihasilkan. Tanin dalam suasana basa dapat memberikan warna merah, sedangkan dalam suasana asam dapat memberikan warna kuning. Apabila ditambahkan $\mathrm{FeSO}_{4}$ alkoholik jenuh dan $\mathrm{NaOH}$ jenuh akan memberikan warna biru sampai hitam (Rahmi dan Burhan, 2000). Tanin merupakan senyawa kimia yang komplek yang terdiri dari beberapa senyawa polifenol yang tersebar luas pada seluruh bagian tumbuhan terutama daun, buah dan kulit kayu dengan bobot molekul antara 500 -3.000 dan mempunyai gugus hidroksi fenolik (Yerimadesi, 2001).

Pengembangan penggunaan pewarna alami saat ini semakin meluas, diantaranya adalah sebagai tinta stempel. Penggunaan tinta stempel masih diperlukan pada administrasi perkantoran.

Tinta adalah cairan yang dapat digunakan untuk menulis, mencetak, menggambar atau keperluan lainnya dan sering juga disebut dengan dawat. Umumnya terbuat dari larutan atau suspensi dengan berbagai zat warna hitam, biru, merah dan lain-lain. Awalnya tinta ini terdiri dari bahan karbonat yang telah dibakar atau campuran jelaga dengan pigmen binatang atau minyak tumbuhan. Tinta tulis berbeda dengan tinta cetak, karena untuk tinta cetak lebih banyak dipakai diindustri grafis. Tinta cetak adalah campuran dari bahan berwarna yang terlarut dan berbentuk cairan atau pasta yang dapat dicetak pada subtrat dan dikeringkan (Muchtar, 2012).

Berdasarkan Standar Nasional Indonesia no.06-1567-1999 Tinta Cap atau tinta stempel merupakan cairan berwarna khusus yang digunakan untuk pencapan pada kertas dengan menggunakan stempel karet.

Peneltian tinta stempel berbahan baku gambir dengan menggunakan senyawa pengomplek $\mathrm{FeCl}_{3}$ dan $\mathrm{FeSO}_{4}$ menghasilkan tinta bewarna biru sampai kehitaman (Muchtar, 2007; 2012). Dalam penelitian pembuatan tinta stempel tersebut perlu ditingkatkan terutama terhadap tingkat homogenitasnya yang masih kurang. Untuk melihat tingkat homogenitas tinta dilakukan dengan meneteskan tinta pada kaca akan terlihat bintik-bintik pada kaca tersebut. Pada tinta yang homogennya baik tidak terdapat bintik-bintik kecil pada gelas atau kaca, sehingga untuk itu perlu ditambahkan dengan zat pengemulsi atau wetting agent.

Menurut Bonajaya (2010) beberapa zat memiliki sifat hidrofob, yaitu sifat yang susah untuk dibasahi. Oleh karena itu diperlukan suatu zat pembasah (wetting agent). Wetting agent sebagai salah satu bahan tambahan yang berfungsi sebagai zat pendispersi seperti propilen glikol, polietilen glikol dan gliserin.

Dalam penelitian ini digunakan gliserin sebagai wetting agent guna mendapatkan tinta yang lebih homogen. Gliserin adalah 
senyawa gliserida yang paling sederhana, dengan hidroksil yang bersifat hidrofilik dan higroskopik, merupakan cairan kental, berasa manis, tidak beracun, tidak berbau, memiliki titik didih tinggi dan membeku dalam bentuk pasta. Bahan ini banyak digunakan sebagai campuran membuat ramuan, bahan kosmetik, obat-obatan. Senyawa ini juga digunakan dalam pengawetan buah-buahan, lotion dan sebagai pelumas (Prasetio et al., 2012; Pagliaro et al., 2008).

Berdasarkan hal tersebut diatas maka dilakukan penelitian dengan tujuan untuk melihat sejauh mana pengaruh gliserin dan konsentrasi larutan ekstrak gambir terhadap beberapa sifat fisika dan kadar tanin tinta.

\section{METODOLOGI PENELITIAN}

Bahan yang digunakan adalah gambir (Uncaria gambier roxb) diambil dari Kenagarian Siguntur Kabupaten Pesisir Selatan, Propinsi Sumatera Barat dari petani pengolah gambir dalam bentuk kering (gambir asalan). Bahan penolong yang digunakan adalah kristal violet (kv), etanol teknis, $\mathrm{NaOH}$ teknis, gliserin, etanol, fero sulfat dan air suling.

Peralatan yang digunakan adalah magnetic stirrer, saringan, wadah plastik, stempel, bantalan stempel dan peralatan pengujian.

\section{Rancangan Penelitian}

Rancangan penelitian adalah Rancangan Acak Lengkap non faktorial, dengan perlakuan Penambahan gliserin (A) yaitu; $0 \%, 15 \%, 20 \%, 25 \%$ dan $30 \%$ serta konsentrasi ekstrak gambir (B) yaitu; $25 \%$, $30 \%, 35 \%, 40 \%$ dan $45 \%$.

\section{Pembuatan tinta stempel}

Pembuatan tinta stempel didahului dengan pembuatan cube black gambir. Gambir direndam dalam air panas dengan perbandingan 1:1, lalu diaduk sampai homogen kemudian disaring dengan saringan halus untuk membuang kotorankotoran yang terbawa sewaktu proses pembuatan gambir. Kemudian larutan gambir dipanaskan pada suhu $\pm 70^{\circ} \mathrm{C}$ sambil diaduk sampai larutan mengental. Selama pemanasan, suhu dijaga konstan dan sedang, bila suhu terlalu tinggi maka akan terjadi pembuihan berlebihan.

Gambir yang telah dikentalkan kemudian dituang dalam loyang, didinginkan semalam dan dipotong-potong. Kemudian dikeringkan dalam suhu ruang sehingga dihasilkan cube black gambir.

Cube black gambir dilarutkan dalam etanol teknis, diaduk dan didiamkan semalam dan disaring. Filtrat ditambahkan dengan larutan ferro sulfat jenuh dalam etanol. Selanjutnya diaduk dengan menggunakan magnetic stirer selama 3 jam, tambahkan kristal violet dan gliserin sesuai dengan variasi, pengadukan dilanjutkan selama 2 jam sampai diperoleh larutan tinta homogen.

\section{Analisis dan pengamatan}

Analisis gambir sebagai bahan baku tinta dilakukan berdasarkan SNI 01-33912000, yaitu kadar air, kadar abu, kadar katechin, kadar bahan tak larut dalam air dan alkohol. Pengamatan yang dilakukan terhadap tinta stempel dengan parameter uji $\mathrm{pH}$, padatan total, dan kadar tanin, sedangkan pengamatan secara visual adalah kekuatan pewarnaan, kelengketan, kekentalan dan homogenitas.

\section{HASIL DAN PEMBAHASAN}

\section{Analisis Bahan Baku Gambir}

Hasil analisis bahan baku gambir yang diperoleh dari daerah Siguntur adalah sebagai berikut : kadar air sebesar 9,1\%, kadar abu 4,3\%, kadar katechin 73\%, kadar bahan tak larut dalam alkohol sebesar $12 \%$ dan kadar bahan tak larut dalam air adalah $5,14 \%$. Gambir yang digunakan sebagai bahan baku dalam pembuatan tinta stempel ini memenuhi persyaratan standar mutu SNI 01-3391 dengan kategori mutu 1.

\section{pH Tinta Stempel}

Derajat keasaman atau $\mathrm{pH}$ digunakan untuk menyatakan tingkat keasaman atau 
kebasaan yang dimiliki oleh suatu larutan. Penetapan $\mathrm{pH}$ tinta ditujukan untuk mencegah terjadinya iritasi pada jari tangan jika $\mathrm{pH}$ tinta rendah dan juga dan tinta digunakan untuk sidik jari. Hasil analisis $\mathrm{pH}$ tinta stempel pada beberapa konsentrasi gliserin dan konsentrasi larutan ekstrak gambir adalah seperti pada Gambar 1 .

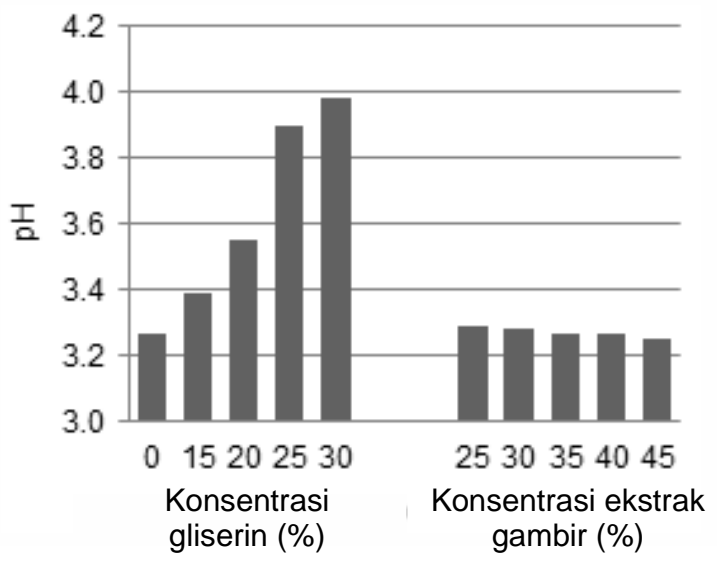

Gambar1. pH tinta stempel dari gambir pada beberapa persentase gliserin dan konsentrasi larutan ekstrakgambir

Hasil analisis $\mathrm{pH}$ tinta stempel dari gambir pada beberapa konsentrasi gliserin berkisar antara 3,39-3,98, pH tinta stempel perlakuan persentase gliserin $30 \%$, memberikan $\mathrm{pH}$ paling tinggi dari semua perlakuan 3,98. Menurut Lucida et al., (2007) yang menjelaskan bahwa katekin mudah teroksidasi pada $\mathrm{pH}$ mendekati netral $(\mathrm{pH}$ 6,9). Sedangkan menurut Bonajaya, (2010) bahwa gliserin mempunyai $\mathrm{pH}$ netral atau $\mathrm{pH}$ 7. Semakin banyak gliserin yang ditambahkan berarti formula tinta stempel mudah teroksidasi sehingga $\mathrm{pH}$ tinta stempel semakin tinggi.

Analisis $\mathrm{pH}$ tinta stempel dilakukan diberbagai perlakuan konsentrasi ekstrak gambir berkisar antara 25\%-45\%, didapatkan $\mathrm{pH}$ tinta stempel pada perlakuan konsentrasi larutan ekstrak gambir 25\% paling tinggi yaitu 3,29, karena esktrak gambir mengandung senyawa asam katechutannat sebagai komponen terbesarnya (20-55\%) (Kasim, 2012), yang bersifat asam dan memberikan $\mathrm{pH}$ yang rendah. Perbedaan persentase penambahan gliserin dapat memberikan nilai $\mathrm{pH}$ yang berbeda dimana dengan meningkatnya penggunaan giserin pada tinta stempel menyebabkan meningkatnya $\mathrm{pH}$ tinta. Begitu juga sebaliknya terjadi pada peningkatan konsentrasi larutan ekstrak gambir akan menurunkan nilai $\mathrm{pH}$ tinta stempel.

\section{Padatan Total Tinta Stempel}

Padatan total merupakan jumlah zat terlarut yang terdapat dalam larutan. Persyaratan minimal padatan total berdasarkan persyaratan standar SNI 061567-1999 adalah 10,0\%. Hasil analisis padatan total tinta stempel dari gambir pada beberapa persentase gliserin dan konsentrasi larutan ekstrak gambir adalah seperti pada Gambar 2. Analisis padatan total tinta stempel dari gambir pada beberapa beberapa konsentrasi gliserin, berkisar antara 33,27\%-38,66\%. Padatan total tinta stempel perlakuan konsentrasi gliserin $15 \%$ adalah paling tinggi yaitu $38,66 \%$ dibandingkan dengan perlakuan lainnya.

Hal ini disebabkan karena pada kondisi asam senyawa katekin lebih reaktif dibandingkan kondisi lain. Gugus fungsional hidroksil $(\mathrm{OH})$ katekin gambir dapat membentuk ikatan kompleks dengan senyawa lain dalam formula tinta stempel, sehing a padatan total perlakuan penambahan gliserin $15 \%$ paling tinggi dibandingkan dengan perlakuan lainnya (Zhu et al., 1997).

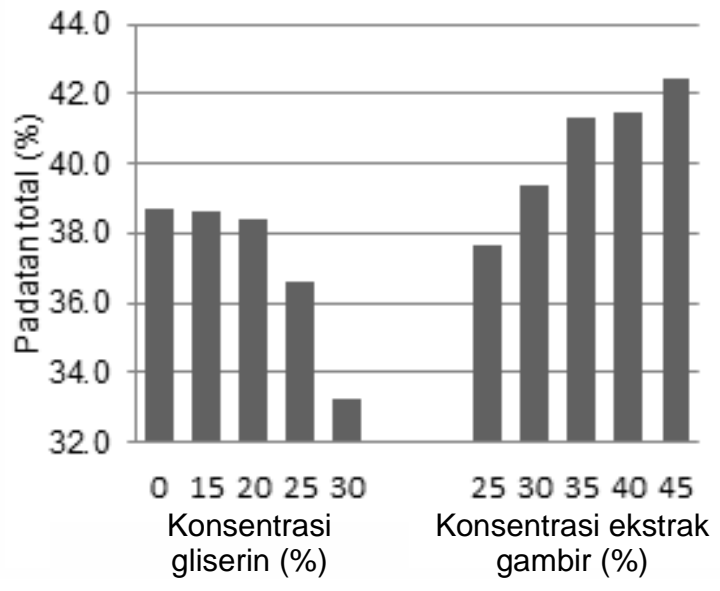

Gambar2. Padatan total stempel dari gambir pada beberapa persentase gliserin dan konsentrasi larutan ekstrak gambir 
Hasil analisis padatan total tinta stempel dari perlakuan beberapa ekstrak gambir seperti pada Gambar 2 padatan total berkisar antara 37,63\%-42,42\%. Padatan total tinta stempel perlakuan konsentrasi ekstrak gambir 45\% (B5), adalah paling tinggi yaitu $42,42 \%$, karena $\mathrm{pH}$ paling rendah. Semakin tinggi ekstrak gambir maka kondisi formula semakin asam dan kereaktifan gugus fungsional $\mathrm{OH}$ katekin semakin meningkat. Hal ini akan meningkatkan kompleksitas dengan senyawa lain dalam formula tinta stempel, sehingga padatan total perlakuan penambahan ekstrak gambir $45 \%$ paling tinggi.

\section{Kadar Tanin dalam Tinta Stempel}

Tanin merupakan senyawa polifenol dari tanaman gambir dengan rasa pahit (sepat) yang larut dalam air. Analisis kadar tanin ditujukan untuk melihat sejauhmana optimalisasi konsentrasi larutan ekstrak gambir yang digunakan. Hasil analisis tanin tinta stempel dari gambir pada beberapa konsentrasi larutan ekstrak gambir adalah sepertipada Tabel 3.

Hasil analisis kadar tanin tinta stempel dari gambir pada beberapa konsentrasi ekstrak gambir, berkisar antara 1,86\%$2,78 \%$. Kadar tanin tinta stempel perlakuan konsentrasi larutan ekstrak gambir $45 \%$, paling tinggi yaitu $2,78 \%$. Semakin tinggi larutan ekstrak gambir yang ditambahkan akan memberikan kadar tanin yang semakin besar. Kadar tanin yang terdeteksi dalam tinta stempel merupakan tanin yang tidak bereaksi membentuk senyawa komplek dengan $\mathrm{FeSO}_{4}$ (Yerimadesi, 2001).

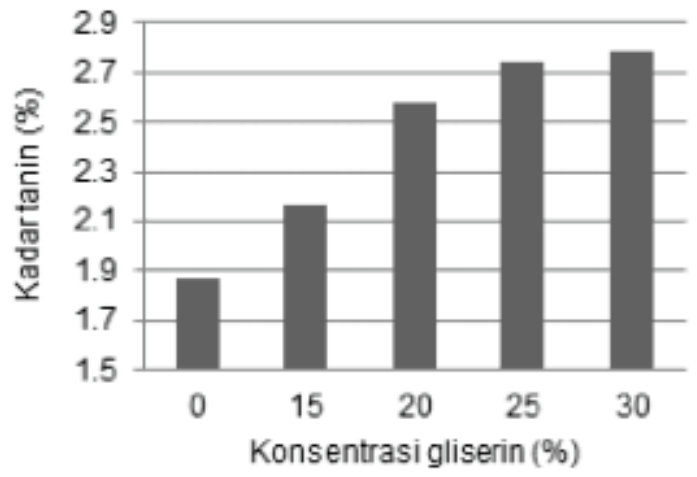

Gambar 3. Kadar Tanin tinta stempel pada beberapa konsentrasi larutan ekstrakgambir

\section{Kekuatan Pewarnaan}

Pengamatan secara visual terhadap kekuatan pewarnaan tinta stempel pada perlakuan beberapa persentase gliserin dan konsentrasi larutan ekstrak gambir adalah seperti Tabel 1.

Tabel1. Pengamatan kekuatan pewarnaan secara visual tinta stempel pada beberapa persentase gliserin dan konsentrasi larutan ekstrak gambir

\begin{tabular}{ccl}
\hline Perlakuan & (\%) & $\begin{array}{c}\text { Kekuatan } \\
\text { Pewarnaan }\end{array}$ \\
\hline Konsentrasi & 0 & Kurang Jelas \\
Gliserin & 15 & Jelas \\
& 20 & Jelas \\
& 25 & Jelas \\
& 30 & Kurang Jelas \\
\hline \multirow{3}{*}{ Ekstrak } & 25 & Kurang Jelas \\
Gambir & 30 & Jelas \\
& 35 & Jelas \\
& 40 & Jelas \\
& 45 & Kurang Jelas \\
\hline
\end{tabular}

Dari Tabel 1 terlihat bahwa penggunaan konsentrasi gliserin 15\%-25\% menghasilkan kekuatan pewarnaan tinta stempel yang jelas dan merata, dan perlakuan 35\% dan $40 \%$ konsentrasi larutan ekstrak gambir kekuatan pewarnaan jelas dan rata, hal ini sesuai dengan sifat kimia tanin semakin besar konsentrasi senyawa organik yang ditambahkan semakin encer sehingga kekuatan pewarnaan kurang jelas dan tidak merata.

\section{Kekentalan}

Pengamatan secara visual terhadap kekentalan tinta stempel pada perlakuan beberapa konsentrasi gliserin dan ekstrak gambir adalah seperti Tabel 2 .

Tabel2. Pengamatan kekentalan tinta stempel pada beberapa persentase gliserin dan konsentrasi larutan ekstrak gambir

\begin{tabular}{ccl}
\hline Perlakuan & $(\%)$ & \multicolumn{1}{c}{ Kekentalan } \\
\hline \multirow{3}{*}{ Konsen- } & 0 & Encer \\
trasi & 20 & Agak Encer \\
Gliserin & 25 & Sedang \\
& 30 & Kedang \\
& 25 & Encer, Mengembang \\
& 30 & Cukup Encer, Mengembang \\
Ekstrak & 35 & Cukup Kental, \\
Gambir & & Tdk Mengembang \\
& 40 & Kental, Tdk Mengembang \\
& 45 & Kental, Tdk Mengembang \\
\hline
\end{tabular}


Dari Tabel 2 terlihat bahwa penggunaan gliserin 15\% menghasilkan tinta stempel yang agak encer sedangkan pada konsentrasi $30 \%$ tinta stempel yang dihasilkan sudah mulai kental. Pada perlakuan konsentrasi larutan ekstrak gambir diperoleh pada penggunaan ekstrak gambir 35\% dan $40 \%$ dihasilkan tinta stempel dengan kekentalan yang cukup dan tidak mengembang bila dicetak pada kertas.

\section{Kelengketan}

Pengamatan kelengketan dilakukan dengan cara mencap tinta pada kertas menggunakan stempel karet. Tinta dinyatakan tidak melengket jika kertas tidak terbawa oleh karet stempel ketika ditarik.

Pengamatan secara visual terhadap kelengketan tinta stempel pada perlakuan beberapa konsentrasi gliserin dan larutan ekstrak gambir adalah seperti Tabel 3. Pada penggunaan gliserin $15 \%$ sampai dengan $25 \%$ dihasilkan tinta stempel yang tidak melengket bila dicetak pada kertas, namun bila konsentrasi dinaikkan menjadi 30\% maka hasil cetakan mulai agak melengket. Perlakuan konsentrasi gambir yang menghasilkan tinta stempel yang tidak melengket pada kertas adalah konsentrasi larutan ekstrak gambir 25\% dan 35\%, sedangkan perlakuan lainnya tinta agak melengket pada kertas. Pada konsentrasi gliserin dan konsentrasi ekstrak larutan gambir tinggi menyebabkan kelengkatan tinta stempel meningkat. Hal ini disebabkan semakin tingginya kekentalan tinta.

Tabel 3. Pengamatan kelengketan tinta stempel pada beberapa konsentrasi gliserin dan larutan ekstrak gambir

\begin{tabular}{ccc}
\hline Perlakuan & $(\%)$ & Kelengketan \\
\hline Konsen- & 0 & Tidak Melengket \\
trasi & 15 & Tidak Melengket \\
Gliserin & 20 & Tidak Melengket \\
& 25 & Tidak Melengket \\
& 30 & Agak Melengket \\
\hline \multirow{2}{*}{ Ekstrak } & 25 & Tidak Melengket \\
Gambir & 30 & Tidak Melengket \\
& 35 & Tidak Melengket \\
& 40 & Agak Melengket \\
\hline
\end{tabular}

\section{Homogenitas tinta}

Pengamatan terhadap homogenitas dari tinta dapat dilihat pada Tabel 4.
Tabel 4. Pengamatan homogenitas tinta stempel pada beberapa konsentrasi gliserin dan larutan ekstrak gambir

\begin{tabular}{ccl}
\hline Perlakuan & $(\%)$ & Homogenitas \\
\hline \multirow{3}{*}{ Konsen- } & 0 & Tidak Homogen \\
trasi & 15 & Kurang Homogen \\
Gliserin & 20 & Homogen \\
& 25 & Homogen \\
& 30 & Homogen \\
Ekstrak & 25 & Homogen \\
Gambir & 30 & Homogen \\
& 35 & Homogen \\
& 40 & Kurang Homogen \\
& 45 & Kurang Homogen \\
\hline
\end{tabular}

Dari hasil pengamatan homogenitas tinta diperoleh bahwa tinta yang ditambah dengan gliserin dengan konsentrasi diatas $15 \%$ memberikan hasil yang lebih homogen jika dibandingkan dengan tanpa penambahan gliserin. Untuk menentukan homogenitas tinta dilakukan pengujian dengan melihat ada tidaknya butiran pada kaca. Pada tinta yang kurang homogennya terdapat bintik-bintik kecil pada gelas atau kaca seperti halnya perlakuan penambahan gliserin pada konsentrasi kecil Ao dan A1, serta penambahan konsentrasi larutan ekstrak yang tinggi.

\section{KESIMPULAN}

Dari hasil penelitian dapat diambil kesimpulan bahwa perbedaan persentase penambahan gliserin dan konsentrasi larutan ekstrak gambir dapat mempengaruhi beberapa sifat fisika tinta terutama terhadap homogenitas tinta. Tinta yang ditambah dengan gliserin diatas $15 \%$ dan penggunaan ekstrak gambir kurang dari $45 \%$ memberikan hasil tinta stempel yang lebih homogen dan tidak melengket. Semakin tinggi konsentrasi gliserin maka $\mathrm{pH}$ tinta juga semakin semakin tinggi, sebaliknya persentase padatan total menjadi turun. Pada perlakuan konsentrasi larutan ekstrak gambir diperoleh kadar tanin berbanding lurus dengan konsentrasi larutan ekstrak gambir dan berbanding terbalik dengan konsentrasi gliserin. Kekuatan pewarnaan yang terbaik adalah pada penambahan gliserin antara 15 - 25 dan penambahan ekstrak larutan gambir antara 35 - 40. Sedangkan untuk kekentalan, kelengketan dan homogenitas adalah pada penggunaan ekstrak gambir 35\%. 


\section{DAFTAR PUSTAKA}

Ardinal, Kasim, A., dan Mutiar, S. 2013. Karakteristik penyamakan kulit menggunakan gambir pada $\mathrm{pH} 4$ dan 8. J. Biopropal Industri, Vol.4 No.2, 2013.

Badan Pusat Statistik. 2014. Sumatera Barat Dalam Angka. Badan Perencanaan dan Pembangunan Daerah Sumbar. Padang.

Badan Standar Nasional Indonesia No.061567-1999, Tinta Cap.

Badan Standar Nasinal Indonesia No. 013391-2000, Gambir.

Bonajaya, A. 2010, Zat pembasah, Jurnal Farmasi, Fak. MIPA, ISTN, Jakarta.

Failisnur dan Sofyan, 2014. Sifat tahan luntur dan intensitas warna kain sutera dengan pewarna alam gambir (Uncaria gambir roxb) pada kondisi pencelupan dan jenis fiksator yang berbeda. Jurnal Litbang Industri Vol.4 No.1, 2014.

Kasim, A. 2012. Proses produksi dan industri hilir gambir, Universitas Andalas Press.

Lucida, H., Bakhtiar, A. dan Putri, W.A. (2007). Formulasi sedian antiseptik mulut dari katekin gambir. Jurnal Sain Teknologi Farmasi 12(1): 1-7.

Muchtar, H dan Silfia. 2007. Pemanfaatan gambir sebagai bahan baku tinta stempel, Bulletin BIPD Vol XV no. 1 hal 1-12, Padang.

Muchtar, H. 2012. Pengaruh jenis senyawa pengomplek terhadap beberapa sifat fisika dan $\mathrm{pH}$ tinta gambir, Prosiding Seminar Nasional Resatek II-2012, Univ Bung Hatta.

Nazir N. 2000. Gambir, budidaya, pengolahan dan prospek diversifikasinya. Padang. Yayasan Hutanku.
Noveri, R., Bakhtiar, A., Deddi, P. 2012. Isolasi katekin dari gambir(Uncaria gambir Roxb) untuk sediaan farmasi dan kosmetik, Jurnal penelitian farmasi Indonesia 1(1), September 2012, 6-10 ISSN 2302. 187X.

Pagliaro, Mario., Rossi, Michele. 2008. The Future of Glycerol: New Uses of a Versatile Raw Material. RSC Green Chemistry Book Series.

Prasetio A.E, Widhi, A., Widayat, 2012. Potensi gliserol dalam pembuatan turunan gliserol melalui proses esterfikasi, Jurnal IImu Lingkungan Vol. 10 No 1 26-31 ISSN 1829-8907.

Rahmi dan Burhans. 2000. Pemanfaatan gambir dan limbahnya sebagai pembuatan tinta, Laporan Penelitian Tekhnik Kimia, Universitas Bung Hatta.

Risfaheri dan Yanti, L. 1993. Pengaruh ketuaan dan penanganan daun sebelum pengempaan terhadap rendemen dan mutu gambir. Bud Littro VIII (I): 46-51.

Santoso, B., Tampubolon, H.S., Wijaya, A., Pabayun. R. 2014. Interaksi pH dan ekstrak gambir pada pembuatan edible film antibakteri. Program studi THP Fak Pertanian Universitas Sriwijaya, J. Agritech, Vol 34 No.1 Feb 2014.

Yerimadesi. 2001. Pengaruh penambahan $\mathrm{Zn}$ (II), Ni dan $\mathrm{Cu}$ (II) terhadap pembentukan kompleks Fe-tanin. Tesis Program Pasca Sarjana Universitas Andalas. Padang.

Zhu, Q.Y., Zhang, A., Tsang, D., Huang, Y. dan Chen, Z.Y. 1997. Stability of green tea catechin. Journal of Agriculture and Food Chemistry 45: 4624-4638. 
